\title{
Pengaruh Kinerja Lingkungan, Pengungkapan Informasi Lingkungan, dan Good Corporate Governance pada Harga Saham Perusahaan
}

\author{
Ni Made Gita Indah Dewi Fortuna ${ }^{1}$ \\ Fakultas Ekonomi dan Bisnis \\ Universitas Udayana, Indonesia \\ Email: gitafortuna12@gmail.com
}

\author{
I Nyoman Wijana Asmara Putra ${ }^{2}$ \\ Fakultas Ekonomi dan Bisnis \\ Universitas Udayana, Indonesia
}

\begin{abstract}
ABSTRAK
Penelitian ini bertujuan untuk mengetahui dan mendapatkan bukti empiris mengenai pengaruh kinerja lingkungan, pengungkapan informasi lingkungan, dan good corporate governance pada harga saham perusahaan. Penelitian ini dilakukan pada perusahaan pertambangan yang terdaftar di Bursa Efek Indonesia tahun 2014-2018. Metode penentuan sampel yang digunakan a dalah metode non probability sampling dengan teknik purposive sampling. Jumlah perusahaan yang memenuhi kriteria adalah 7 perusahaan denganjumlah a ma tan sebanyak 35 dalam 5 tahun. Teknik analisis data yang digunakan dalam penelitian ini a dalah analisis regresi linier berganda. Hasil analisis menunjukkan bahwa kinerja lingkungan, pengungkapan informasi lingkungan, dan kepemilikan institusional berpengaruh positif pada harga saham perusahaan.
\end{abstract}

Kata Kunci: Harga Saham; Kinerja Lingkungan; Pengungkapan Informasi Lingkungan; Good Corporate Governance.

The Influence of Environmental Performance, Environmental Disclosure, and Good Corporate Governance on Company's Stock Price

\section{ABSTRACT}

This study aims to empirically examine the influence of environmental performance, environmental disclosure, and good corporate governance on stock prices of mining company listed in Indonesian Stock Exchange around 2014 to 2018. The research sample was selected using the nonprobability sampling method with a purposive sampling technique and obtained as many as seven companies, so that the number of observations with a study period of 5 years was 35 observations. The data analysis was analysed by using the multiple linear regression technique. The result show that environmental performance, environmental disclosure, and good corporate governance positively affected companies' stock prices in the market.

$\begin{array}{ll}\text { Keywords: } & \text { Stock Price; Environmental Performance; } \\ & \text { Environmental Disclosure; Good Corporate } \\ & \text { Governance. }\end{array}$

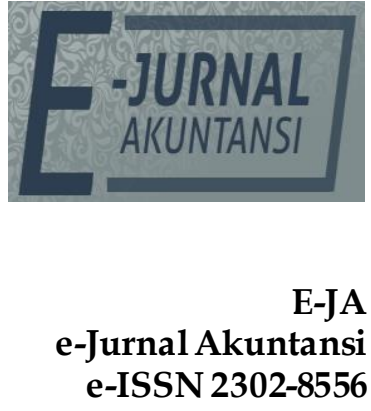

Vol. 30 No. 4 Denpasar, April 2020

Hal.1019-1033

Artikel Masuk: 8 Januari 2020

Tanggal Diterima: 27 Februari 2020 


\section{PENDAHULUAN}

Pertimbangan, perhitungan, dan analisis yang tepat terhadap suatu informasi merupakan hal yang penting bagi investor dalam berinvestasi (Basu, 1977). Hal ini diperlukan untuk mengetahui prospek perusahaan yang akan menjual sahamnya. Hal yang wajib dijadikan bahan pertimbangan seorang investor sebelum berinvestasi salah satunya adalah harga saham. Harga saham merupakan harga yang dibentuk dari mekanisme pasar berupa permintaan dan penawaran oleh para penjual dan pembeli saham yang dilatarbelakangi oleh harapan terhadap profit perusahaan (Sulia, 2017). Secara umum, perusahaan yang dinilai baik dan disukai investor adalah perusahaan yang mempunyai stabilitas harga saham dan mempunyai pola pergerakan yang cenderung naik dari waktu ke waktu (Pribadi, 2016). Pada kenyataannya, harga saham di pasar modal selalu mengalami fluktuasi. Naik turunnya harga saham di pasar modal menjadi sebuah fenomena yang menarik bagi investor. Fluktuasi harga saham membuat investor sulit menentukan kapan saat yang tepat untuk membeli atau menjual suatu saham (Aryani \& Cintyawati, 2018). Harga saham yang tinggi dapat menunjukkan kepada investor bahwa perusahaan dapat memberikan pengembalian investasi yang memadai (Wahyuni, 2018). Harga saham dalam penelitian ini diukur dengan harga saham penutupan (closing price). Kinerja perusahaan yang baik akan menarik minat investor untuk menanamkan modal di perusahaan tersebut. Semakin baik kinerja perusahaan maka semakin tinggi laba yang didapatkan dan semakin banyak keuntungan yang akan didapatkan oleh pemegang saham. Serta akan meningkatkan citra atau reputasi perusahaan di mata masyarakat dan pada akhirnya dapat meningkatkan harga saham (Tanjung, 2013).

Keberhasilan perusahaan juga dapat dilihat dari kontribusi yang diberikan oleh perusahaan kepada lingkungannya (Deák \& Karali, 2014). Ketika perusahaan mulai melakukan operasi bisnis, akan berpotensi memiliki dampak bagi lingkungan. Masyarakat semakin kritis dan memandang aktivitas ind ustri pertambangan sebagai kontributor utama atas permasalahan lingkungan (Sarumpaet, 2006). Untuk itu perusahaan dalam menjalankan strategi bisnisnya harus mulai memperhatikan dan peduli akan kondisi sosial dan lingkungannya serta berupaya agar operasi bisnis mereka seminimal mungkin berdampak negatif pada lingkungan.

Dalam usaha meningkatkan kepedulian perusahaan terhadap lingkungan, pada tahun 1995 Pemerintah membuat Program Kali Bersih (PROKASIH) kemudian dikembangkan menjadi Program Penilaian Peringkat Kinerja Perusahaan dalam Pengelolaan Lingkungan Hidup (PROPER) (KLHK RI, 2018). Hal ini untuk mengendalikan dampak buruk pada lingkungan yang mungkin terjadi akibat dari kegiatan operasi perusahaan. Namun dalam kenyataannya, masih ada perusahaan yang tidak memperhatikan dampak buruk pada lingkungan akibat aktivitas perusahaan, misalnya PT. Dwinad Nusa Sejahtera (DNS). PT. DNS merupakan perusahaan pertambangan emas yang beroperasi di Sumatera Selatan. Berdasarkan Keputusan Menteri Lingkungan Hidup dan Kehutanan RI Nomor SK.613/Menlhk/Setjen/KUM.1/12/2018 tentang Hasil Penilaian Peringkat Kinerja Perusahaan dalam Pengelolaan Lingkungan Hidup Tahun 2017-2018, PT. DNS berada pada nomor kedua peringkat hitam PROPER 
yang berarti perusahaan tidak memiliki kepedulian sama sekali terhadap lingkungan (KLHK RI, 2018). Perusahaan ini diduga membuang limbah ke Sungai Tiku di Kecamatan Karang Jaya, Kabupaten Musi Rawas Utara, pada saat air sungai meningkat setiap terjadi hujan. Isu ini menyebabkan masyarakat menuntut perusahaan bertanggung jawab atas pencemaran yang terjadi. Fenomena tersebut tentu membuat citra perusahaan menurun dan tentunya berdampak pada nilai perusahaan dengan menurunnya harga saham (Saputra, 2018). Berbagai permasalahan lingkungan yang terjadi mulai menjadi sorotan publik ketika lingkungan mulai tidak sehat (Wijaya \& Nuryatno, 2019). Masalah kerusakan lingkungan akibat dari aktivitas perusahaan harus menjadi tanggung jawab perusahaan itu sendiri dan segala keputusan terkait pemeliharaan lingkungan sudah seharusnya lebih dipertimbangkan. Berkaitan dengan teori sinyal, dengan mencatat dan mengungkapkan biaya lingkungan perusahaan diharapkan dapat memberi good news kepada investor serta dapat menarik minat investor untuk mempertimbangkan informasi pengungkapan informasi lingkungan tersebut dalam pengambilan keputusan investasi (Kusuma \& Dewi, 2019).

Ketika menjalankan kegiatan bisnis, perusahaan membutuhkan suatu sistem yang membuat kinerjanya terarah dan terkendali. Hal tersebut bisa tercapai dengan menerapkan good corporate governance pada perusahaan. Perusahaan yang memiliki tata kelola yang baik akan berjalan lebih efisien karena aktivitasnya terkendali dengan baik (Ainy \& Barokah, 2016). GCG diharapkan akan dapat meminimalisir dampak buruk yang tidak diinginkan serta dapat meningkatkan kinerja perusahaan sehingga mampu menarik minat investor dan berdampak pada peningkatan harga saham (Yasa et al., 2019).

Kinerja lingkungan adalah mekanisme bagi perusahaan untuk secara sukarela mengintegrasikan perhatian terhadap lingkungan ke dalam operasinya dan interaksinya dengan stakeholder (Reni \& Anggraini, 2006). Kinerja lingkungan adalah kinerja perusahaan dalam menciptakan lingkungan yang baik (green) (Suratno et al., 2004). Kinerja lingkungan dalam penelitian ini diukur dengan penilaian peringkat PROPER yang dilakukan oleh Kementerian Lingkungan Hidup dan Kehutanan RI. Perusahaan yang meraih peringkat PROPER yang tinggi dianggap memiliki kepedulian yang tinggi pada lingkungan, hal ini akan meningkatkan kepercayaan investor sehingga dapat meningkatkan harga saham perusahaan. Rahmawati \& Subardjo (2017) menemukan bahwa kinerja lingkungan berpengaruh terhadap harga saham. Suratno et al. (2004) serta Titisari \& Alviana (2012) yang menemukan bahwa kinerja lingkungan berpengaruh terhadap kinerja ekonomi. Namun pada penelitian yang dilakukan oleh Almilia \& Wijayanto (2007) serta Wulandari \& Hidayah (2013) menemukan bahwa kinerja lingkungan tidak berpengaruh terhadap harga saham.

Pengungkapan lingkungan merupakan salah satu pengungkapan sukarela yang merupakan bagian dari pelaporan tanggung jawab sosial perusahaan. Pengungkapan lingkungan yang dilakukan oleh perusahaan merupakan wujud tanggung jawab perusahaan dalam menjaga dan melestarikan lingkungan (Busru

\& Shanmugasundaram, 2017). Pengungkapan informasi lingkungan diukur dengan indeks Global Reporting Initiative Generation 4 (GRI G4) bagian aspek lingkungan dengan metode skoring. Tingginya pengungkapan informasi 
lingkungan yang dilakukan olehpperusahaan menunjukkan bahwa perusahaan secara maksimal telah memberikan informasi tanggung jawab lingkungan. Informasi lingkungan yang disajikan tersebut dapat dijadikan sebagai bahan pertimbangan oleh investor dalam mengambil keputusan investasi. Semakin lengkap informasi yang didapat stakeholder, maka akan semakin mempengaruhi keputusan yang diambil oleh para stakeholder (Cohen et al., 2011). Penelitian yang dilakukan oleh Wulandari dan Hidayah (2013) yang menemukan adanya pengaruh signifikan antara variabel pengungkapan informasi lingkungan pada harga saham. Penelitian oleh Suratno et al. (2004), Saputra (2016), serta Rahmawati \& Subardjo (2017) pun juga menemukan bahwa pengungkapan lingkungan berpengaruh terhadap harga saham.

Forum for Corporate Governance in Indonesia-FCGI (2001), mengartikan GCG sebagai seperangkat peraturan yang mengatur hubungan antara manajer, pemegang saham, pemerintah, kreditur, staf, serta pihak lain yang memiliki kepentingan dalam suatu perusahaan yang berkaitan dengan hak dan kewajiban mereka, GCG juga dapat didefinisikan sebagai suatu mekanisme yang mampu mengatur sekaligus mengendalikan suatu perusahaan. Hubungan keagenan (agency relationship) terjadi ketika satu atau lebih individu, yang disebut sebagai prinsipal menyewa individu atau organisasi lain, yang disebut sebagai agen, untuk melakukan sejumlah jasa dan medelegasikan kewenangan untuk membuat keputusan kepada agen tersebut (Brigham \& Houston, 2006). GCG diterapkan untuk menciptakan kepercayaan antara perusahaan dan pemangku kepentingan (Samontaray, 2010). Variabel GCG dalam penelitian ini diwakilkan oleh proksi yang akan dianalisis dengan menggunakan analisis faktor. Proksi yang digunakan adalah proksi yang lulus uji analisis faktor dan memiliki pengaruh paling tinggi. Keempat mekanisme good corporate governance diukur terlebih dahulu dengan formulasinya masing-masing. Penelitian yang dilakukan oleh Drobetz (2004), Mohamed \& Elewa (2016) serta Ningsih \& Atmadja (2017) menemukan bahwa GCG berpengaruh positif pada harga saham.

Penelitian sebelumnya yang dilakukan oleh Wulandari \& Hid ayah (2013) yang menguji pengaruh kinerja lingkungan dan pengungkapan informasi lingkungan terhadap kinerja ekonomi pada perusahaan manufaktur yang terdaftar di BEI selama 2009-2011. Adapun perbedaan penelitian ini dengan penelitian tersebut yaitu pada periode penelitian, sampel penelitian, dan pada penelitian ini penulis menambahkan variabel independen good corporate governance. Penelitian ini meneliti pengaruh penerapan kinerja lingkungan, pengungkapan informasi lingkungan, dan good corporate governance pada harga saham pada perusahaan pertambangan yang terdaftar di BEI tahun 2014-2018. Penambahan variabel good corporate governance dikarenakan peneliti ingin mengetahui pengaruh good corporate governance terhadap harga saham pada perusahaan peserta PROPER sesuai kriteria sampel pada penelitian ini.

Grand theory dalam penelitian ini yaitu teori sinyal. Pihak perusahaan akan memberikan sinyal dalam bentuk informasi yang relevan kepada pihak eksternal dan kemudian pihak eksternal akan menyesuaikan keputusannya sesuai dengan pemahamannya terhadap sinyal tersebut (Spence, 1973). Dengan sinyal yang diperoleh pihak eksternal dapat menjadi informasi yang berguna untuk bahan pertimbangan dalam mengambil keputusan investasi. 
Kinerja lingkungan yang baik dapat menjadi sinyal bagi investor bahwa perusahaan telah memberikan kontribusi dalam menjaga dan melestarikan lingkungan. Besarnya kepedulian perusahaan di dalam kegiatan lingkungan, maka bertambah baik juga reputasi perusahaan di mata stakeholder maupun pengguna laporan keuangan. Dengan adanya reputasi positif, maka akan da pat menarik perhatian dari para stakeholder maupun masyarakat pengguna laporan keuangan. Berdasarkan teori stakeholder, perusahaan harus dapat menyelaraskan kepentingan perusahaan dengan kepentingan stakeholder-nya. Kinerja lingkungan yang dilakukan dengan baik oleh perusahaan akan membuat kinerja ekonomi perusahaan tersebut juga semakin baik, sehingga akan direspon secara positif oleh pasar melalui fluktuasi harga saham. Pernyataan ini didukung oleh Rahmawati \& Subardjo (2017) menemukan bahwa kinerja lingkungan berpengaruh terhadap harga saham. Suratno et al. (2004), Ziegler et al. (2007) serta Titisari \& Alviana (2012) yang menemukan hubungan positif antara kinerja ekonomi dengan kinerja lingkungan. Berdasarkan uraian diatas, maka hipotesis yang diajukan adalah sebagai berikut.

$\mathrm{H}_{1}$ : Kinerja lingkungan berpengaruh positif padaharga saham.

Pengungkapan informasi lingkungan juga dapat menjadi sinyal bagi pengguna laporan keuangan bahwa perusahaan telah menyajikan informasi lingkungan ke dalam laporan tahunannya. Berdasarkan teori stakeholder yang menyatakan bahwa semua stakeholder mempunyai hak memperoleh informasi mengenai aktivitas perusahaan yang bisa mempengaruhi pengambilan keputusan mereka. Perusahaan yang memiliki pengungkapan informasi lingkungan yang baik akan memberikan informasi yang lebih bisa diandalkan oleh stakeholder. Oleh sebab itu, suatu pengungkapan yang dilakukan oleh perusahaan akan membuat investor percaya kinerja perusahaan juga telah dijalankan dengan baik sehingga dapat meningkatkan citra dan nilai perusahaan serta mampu mempengaruhi para investor untuk berinvestasi. Semakin banyak permintaan akan saham dari para investor maka akan berdampak pada peningkatan harga saham. Pernyataan ini didukung oleh Wulandari \& Hidayah (2013), Suratno et al. (2004), Saputra (2016), serta Rahmawati \& Subardjo (2017) yang menemukan bahwa pengungkapan lingkungan berpengaruh positif terhadap harga saham. Berdasarkan uraian diatas, maka hipotesis yang diajukan adalah sebagai berikut.

$\mathrm{H}_{2}$ : Pengungkapan informasi lingkungan berpengaruh positif terhadap harga saham.

Penerapan good corporate governance dapat menjadi sinyal bagi investor bahwa pengelolaan manajemen perusahaan terkendali dengan baik. Menurut Jensen \& Meckling (1976), teori keagenan menjelaskan adanya hubungan antara prinsipal dengan agen. GCG diterapkan untuk mengurangi masalah keagenan. GCG dipercaya dapat meningkatkan nilai perusahaan yang terlihat dari pergerakan harga saham. Perusahaan yang menerapkan GCG akan berjalan lebih efisien karena aktivitasnya terkendali dengan baik. Dengan begitu dapat meminimalisir dampak buruk yang tidak diinginkan serta dapat meningkatkan kinerja perusahaan sehingga mampu menarik minat investor dan akan berdampak pada peningkatan harga saham. Pernyataan ini didukung oleh Mohamed \& Elewa (2016) serta Ningsih \& Atmadja (2017) menemukan bahwa 
GCG berpengaruh positif pada harga saham. Berdasarkan uraian diatas, maka hipotesis yang diajukan adalah sebagai berikut.

$\mathrm{H}_{3}$ : Good corporate governance berpengaruh positif pada harga saham.

\section{METODE PENELITIAN}

Jenis penelitian ini menggunakan penelitian asosiatif dengan pendekatan kuantitatif. Penelitian ini dilakukan pada perusahaan sektor pertambangan yang terdaftar di Bursa Efek Indonesia tahun 2014-2018. Objek penelitian ini adalah harga saham perusahaan pertambangan yang terdaftar di Bursa Efek Indo nesia tahun 2014-2018 dengan kinerja lingkungan, pengungkapan informasi lingkungan, dan good corporate governance sebagai variabel independen. Variabel dependen dalam penelitian ini yaitu harga saham $(\mathrm{Y})$, sedangkan variabel independen pada penelitian ini yaitu kinerja lingkungan $\left(X_{1}\right)$, pengungkapan informasi lingkungan $\left(\mathrm{X}_{2}\right)$, dan good corporate governance $\left(\mathrm{X}_{3}\right)$.

Harga saham merupakan harga yang dibentuk dari mekanisme pasar berupa permintaan dan penawaran oleh para penjual dan pembeli saham yang dilatarbelakangi oleh harapan terhadap profit perusahaan (Sulia, 2017). Harga saham dalam penelitian ini menggunakan harga saham penutupan (closing price) tutup tahun.

Kinerja lingkungan dalam penelitian ini diukur dengan peringkat PROPER. PROPER merupakan program pemeringkatan dalam rangka mengevaluasi kinerja atau upaya perusahaan dalam menjaga dan melestarikan lingkungan. Program ini diselenggarakan oleh Kementerian Lingkungan Hid up dan Kehutanan RI.

Tabel 1. Kategori Peringkat PROPER

\begin{tabular}{lcc}
\hline Peringkat & Skor & Keterangan \\
\hline Emas & 5 & Sangat-Sangat Baik \\
Hijau & 4 & Sangat Baik \\
Biru & 3 & Baik \\
Merah & 2 & Buruk \\
Hitam & 1 & Sangat Buruk \\
\hline
\end{tabular}

Sumber: KLHKRI, 2019

Pengungkapan informasi lingkungan dalam penelitian ini dinilai menggunakan indeks GRI G4 bagian aspek lingkungan dengan metode skoring. Setelah pengungkapan informasi lingkungan dinilai berdasarkan d af tar ind eks pengungkapan lingkungan, kemudian skor akhir akan dihitung sebagai berikut. Skor akhir $=\frac{\text { Total pengungkapan lingkungan yang dilakukan }}{\text { Total pengungkapan lingkungan yang seharusnya dilakukan }}$

Variabel GCG dalam penelitian ini diwakilkan oleh proksi yang akan dianalisis dengan menggunakan analisis faktor. Proksi yang digunakan adalah proksi yang lulus uji analisis faktor dan memiliki pengaruh paling tinggi. Keempat mekanisme good corporate governance diukur terlebih dahulu dengan formulasinya masing-masing.

Populasi dalam penelitian ini adalah seluruh perusahaan pertambangan yang terdaftar di Bursa Efek Indonesia periode 2014-2018. Sampel penelitian ini adalah perusahaan pertambangan yang telah diseleksi menggunakan metode non probability sampling dengan teknik purposive sampling. Jenis data dalam penelitian ini yaitu data kuantitatif berupa peringkat PROPER, skor 
pengungkapan informasi lingkungan, penilaian GCG, dan harga saham yang terdapat pada annual report perusahaan pertambangan selama periode 2014-2018. Sumber data penelitian ini adalah data sekunder berupa annual report perusahaan pertambangan periode 2014-2018 yang dipublikasi pada website Bursa Efek Indonesia (BEI) yang diakses melalui www.idx.co.id. Penelitian ini menggunakan metode nonparticipant observation.

Teknik analisis data dalam penelitian ini adalah analisis regresi linear berganda yang bertujuan untuk mengetahui pengaruh kinerja lingkungan, pengungkapan informasi lingkungan, dan good corporate governance pada harga saham perusahaan pertambangan yang terdaftar di BEI periode 2014-2018. Data yang diperoleh diuji terlebih dahulu dengan menggunakan uji asumsi klasik untuk menghasilkan model regresi yang bersifat BLUE (Best Linier Unbiased Estimator), kemudian dilanjutkan diuji dengan analisis regresi linear berganda. Adapun persamaan regresi yang digunakan dalam penelitian ini sebagai berikut:

$$
Y=\alpha+\beta_{1} . X_{1}+\beta_{2} . X_{2}+\beta_{3} . X_{3}+e
$$

Keterangan:

$$
\begin{array}{ll}
\mathrm{Y} & =\text { Harga Saham } \\
\mathrm{a} & =\text { Konstanta } \\
\beta_{1}-\beta_{3} & =\text { Koefisien Regresi } \\
\mathrm{X}_{1} & =\text { Kinerja Lingkungan } \\
\mathrm{X}_{2} & =\text { Pengungkapan Informasi Lingkungan } \\
\mathrm{X}_{3} & =\text { Good Corporate Governance (GCG) } \\
\mathrm{e} & =\text { error }
\end{array}
$$

\section{HASIL DAN PEMBAHASAN}

Sampel perusahaan yang memenuhi kriteria yaitu sebanyak 7 perusahaan yang diseleksi menggunakan teknik purposive sampling. Adapun seleksi sampel dilakukan dengan kriteria berikut.

\section{Tabel 2. Hasil Seleksi Sampel berdasarkan Kriteria}

\begin{tabular}{clc}
\hline No & Keterangan & Jumlah \\
\hline 1 & Jumlah perusahaan pertambangan yang terdaftar di BEI hingga tahun & 49 \\
& 2019 & \\
2 & $\begin{array}{l}\text { Perusahaan pertambangan yang tidak mengikuti atau terdaftar sebagai } \\
\text { peserta PROPER berturut-turut periode 2014-2018 }\end{array}$ & $(42)$ \\
& Total sampel penelitian & 7 \\
& Jumlah tahun pengamatan & 5 \\
& Jumlah observasi yang memenuhi kriteria selama periode2014-2018 & 35 \\
\hline
\end{tabular}
Sumber: Data Penelitian, 2019

Analisis faktor dalam penelitian ini digunakan untuk mereduksi variabel dewan komisaris independen, komite audit, kepemilikan manajerial, dan kepemilikan institusional yang diberi nama good corporate governance. Adapun hasil dari analisis faktor dapat dilihat pada Tabel 3.

Tabel 3. menunjukkan nilai KMO sebesar 0,404 dimana nilai tersebut lebih kecil dari 0,5 . Dengan kondisi demikian faktor dengan nilai anti-image correlation terendah harus dikeluarkan (Utama, 2016). Sehingga komite audit dikeluarkan dan didapat hasil analisis sebagai berikut. 
Tabel 3. Hasil Pertama Uji KMO and Bartlett's Test

\begin{tabular}{lll}
\hline Kaiser-Meyer-Olkin Measure of Sampling Adequacy. & 0,404 \\
Bartlett's Test of Sphericity & Approx. Chi-Square & 9.660 \\
& Df & 6 \\
Anti Image Correlation & Sig. & 0,140 \\
DKI & & \\
KA & & 0,285 \\
KM & & 0,275 \\
KI & 0,421 \\
\hline
\end{tabular}

Sumber: Data Penelitian, 2019

Tabel 4. memperlihatkan variabel GCG memiliki nilai KMO sebesar 0,510. Hal ini menyimpulkan bahwa masing-masing indikator GCG yang terdiri dari dewan komisaris independen, kepemilikan manajerial, dan kepemilikan institusional memiliki kecukupan sampel untuk analisis faktor. Berdasarkan Tabel 4. dapat diketahui bahwa seluruh variabel GCG memiliki nilai anti image correlation lebih dari 0,5. Dengan demikian maka dewan komisaris ind ependen, kepemilikan manajerial, dan kepemilikan institusional dapat mengkonfirmasikan variabel GCG.

Tabel 4. Hasil Kedua Uji KMO and Bartlett's Test

\begin{tabular}{|c|c|c|}
\hline \multicolumn{2}{|c|}{ Kaiser-Meyer-Olkin Measure of Sampling Adequacy. } & 0,510 \\
\hline & Approx. Chi-Square & 1.165 \\
\hline \multirow{2}{*}{ Bartlett's Test of Sphericity } & Df & \\
\hline & Sig. & 0,000 \\
\hline \multicolumn{3}{|l|}{ Anti Image Correlation } \\
\hline DKI & & 0,507 \\
\hline KM & & 0,508 \\
\hline KI & & 0,547 \\
\hline
\end{tabular}
Sumber: Data Penelitian, 2019

Tabel 5. menunjukkan bahwa nilai loading faktor tertinggi adalah kepemilikan institusional, sehingga kepemilikan institusional merupakan proksi terbaik yang digunakan untuk mengukur GCG dalam penelitian ini.

Tabel 5. Nilai Communalities

\begin{tabular}{lll}
\hline & Initial & Extraction \\
\hline DKI & 1,000 & 0,565 \\
KM & 1,000 & 0,502 \\
KI & 1,000 & 0,632 \\
\hline
\end{tabular}

Sumber: Data Penelitian, 2019

Statistik deskriptif disajikan untuk memberikan informasi mengenai karakteristik variabel penelitian, seperti nilai minimum, nilai maksimum, nilai rata-rata serta standar deviasi. Hasil statistik deskriptif setiap variabel disajikan pada Tabel 6. 
Tabel 6. Hasil Uji Statistik Deskriptif

\begin{tabular}{llrrrr}
\hline & N & Minimum & Maximum & \multicolumn{1}{c}{ Mean } & Std. Deviation \\
\hline Harga Saham & 35 & 220,00 & $12.500,00$ & $2.253,4571$ & $2.822,13627$ \\
KL & 35 & 3,00 & 5,00 & 3,8857 & 0,86675 \\
PL & 35 & 0,12 & 0,94 & 0,4227 & 0,19062 \\
GCG (KI) & 35 & 0,43 & 0,81 & 0,6415 & 0,24763 \\
Valid N (listwise) & 35 & & & &
\end{tabular}

Sumber: Data Penelitian, 2019

Variabel harga saham yang diproksikan dengan closing price menunjukkan hasil bahwa sampel dalam penelitian ini sebanyak 35. Variabel harga saham memiliki nilai minimum sebesar 220 yaitu harga saham dari PT Surya Esa Perkasa Tbk, (ESSA) tahun 2017. Nilai maksimum dari variabel harga saham yaitu sebesar 12.500 dari PT Bukit Asam Tbk, (PTBA) tahun 2016. Har ga saham cenderung rendah dilihat dari rata-ratanya yaitu sebesar 2.253,4571 dengan standar deviasi sebesar 2.822,13627. Nilai standar deviasi yang lebih besar dari nilai rata-rata berarti terdapat fluktuasi yang tinggi pada harga saham perusahaan pertambangan pada sampel penelitian ini.

Kinerja lingkungan memiliki nilai minimum sebesar 3 (peringkat biru) sedangkan nilai maksimum yaitu sebesar 5 (peringkat emas). Nilai rata-ratanya yaitu sebesar 3,8857 yang berarti perusahaan yang dijadikan sampel telah melakukan kinerja lingkungan secara optimal dan meraih peringkat lebih dari taat, serta standar deviasi yang lebih kecil dari nilai rata-rata yaitu sebesar 0,86675 menunjukkan sebaran data sudah merata. Pengungkapan informasi lingkungan memiliki nilai minimum sebesar 0,12 , sedangkan nilai maksimum yaitu sebesar 0,94 . Nilai rata-ratanya yaitu sebesar 0,4227 yang mendekati nilai minimum yang berarti pengungkapan informasi lingkungan pada perusahaan yang dijadikan sampel masih tergolong rendah. Standar deviasi sebesar 0,19062 yang lebih kecil dari nilai rata-rata berarti sebaran data sudah merata. Kepemilikan institusional memiliki nilai minimum sebesar 0,43, sedangkan nilai maksimum yaitu sebesar 0,81 . Nilai rata-rata kepemilikan institusional yaitu sebesar 0,6415 mendekati nilai maksimum yang berarti kepemilikan institusional pada perusahaan yang dijadikan sampel cenderung tinggi, serta standar deviasi sebesar 0,24763 berarti sebaran data kepemilikan institusional sudah merata.

Hasil analisis regresi linier berganda dapat dilihat pada Tabel 7 berikut.

Tabel 7. Rangkuman Hasil Analisis Regresi Linear Berganda

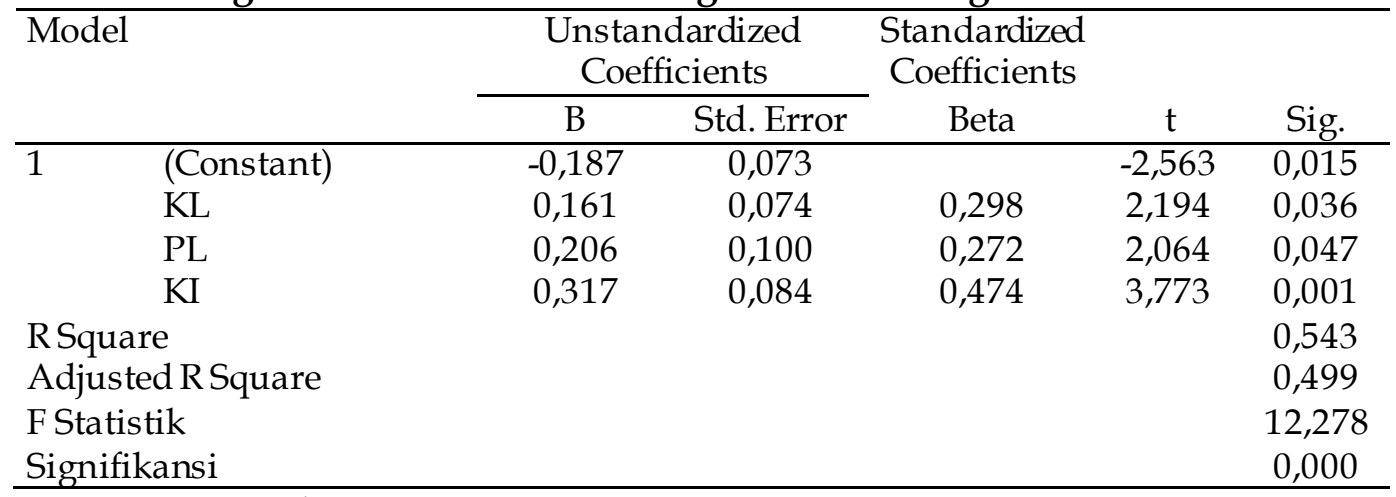

Sumber: Data Penelitian, 2019 
Berdasarkan hasil analisis regresi linier berganda pada Tabel 7, maka dapat dibuat persamaan regresi sebagai berikut.

$$
\mathrm{Y}=-0,187+0,161 \mathrm{X}_{1}+0,206 \mathrm{X}_{2}+0,317 \mathrm{X}_{3}
$$

Nilai konstanta $(\alpha)$ sebesar $-0,187$ memiliki arti apabila nilai variabel independen sama dengan nol, maka variabel $Y$ bernilai sebesar $-0,187$. Nilai koefisien regresi $X 1=0,161$ artinya apabila nilai kinerja lingkungan mengalami peningkatan satu persen maka harga saham perusahaan akan bertambah sebesar 16,1 persen dengan asumsi variabel independen lainnya konstan. Nilai koefisien regresi $X 2=0,206$ artinya bila nilai pengungkapan informasi lingkungan mengalami peningkatan satu persen maka harga saham perusahaan akan meningkat sebesar 20,6 persen dengan anggapan variabel independen lainnya konstan. Nilai koefisien regresi $X 3=0,317$ artinya bila nilai GCG mengalami peningkatan satu persen maka harga saham perusahaan akan meningkat sebesar 31,7 persen dengan asumsi variabel independen lainnya konstan.

Hasil uji $\mathrm{F}$ (F-test) menunjukkan bahwa nilai $\mathrm{F}$ Hitung sebesar 12,278 dengan nilai signifikansi P value 0,000 lebih kecil dari $\alpha=0,05$, ini berarti model yang digunakan pada penelitian ini adalah layak. Hasil ini memberikan makna bahwa seluruh variabel independen mampu memprediksi atau menjelaskan fenomena harga saham pada perusahaan pertambangan yang terdaftar di Bursa Efek Indonesia (BEI) pada tahun 2014-2018. Hal ini berarti secara simultan kinerja lingkungan $\left(X_{1}\right)$, pengungkapan informasi lingkungan $\left(X_{2}\right)$ dan $G C G\left(X_{3}\right)$ berpengaruh signifikan pada harga saham. Uji koefisien determinasi $\left(\mathrm{R}^{2}\right)$ digunakan untuk mengetahui dan mengukur kemampuan model dalam menerangkan variasi variabel independen. Hasil uji memberikan hasil dimana diperoleh besarnya adjusted $\mathrm{R}^{2}$ (koefisien determinasi yang telah disesuaikan) adalah 0,499. Ini berarti variasi harga saham perusahaan pertambangan yang terdaftar di Bursa Efek Indonesia (BEI) pada tahun 2014-2018 dapat dipengaruhi secara signifikan oleh variabel kinerja lingkungan $\left(X_{1}\right)$, pengungkapan informasi lingkungan $\left(X_{2}\right)$, dan GCG $\left(X_{3}\right)$ sebesar 49,9 persen sedangkan sisanya sebesar 50,1 persen dijelaskan oleh faktor-faktor lain yang tidak dijelaskan dalam penelitian ini.

Dari Tabel 7. diketahui bahwa nilai koefisien regresi kinerja lingkungan adalah sebesar 0,161 dengan tingkat signifikansi 0,036 lebih kecil dari tingkat signifikansi 0,050. Hal ini menunjukkan bahwa kinerja lingkungan berpengaruh positif dan signifikan terhadap harga saham. Maka hipotesis yang menyatakan bahwa kinerja lingkungan berpengaruh positif pada harga saham, diterima. Hasil penelitian ini sejalan dengan Flammer (2013), Prabandari \& Suryanawa (2014), Rahmawati \& Subardjo (2017) serta Teja et al. (2018). Berdasarkan teori stakeholder, perusahaan harus dapat menyelaraskan kepentingan perusahaan dengan kepentingan stakeholder-nya. Semakin besar andil perusahaan di dalam kegiatan lingkungan, maka semakin baik pula image perusahaan di mata stakeholder maupun pengguna laporan keuangan. Dengan adanya image positif tersebut, maka akan dapat menarik perhatian dari para stakeholder maupun masyarakat pengguna laporan keuangan. Maka dengan kinerja lingkungan perusahaan yang meningkat akan semakin baik pula kinerja ekonomi perusahaan tersebut, sehingga pasar akan merespon secara positif melalui fluktuasi harga saham. 
Dari Tabel 7. diketahui bahwa nilai koefisien regresi pengungkapan informasi lingkungan adalah sebesar 0,206 dengan tingkat signifikansi sebesar 0,047 lebih kecil dari tingkat signifikansi 0,050. Hal ini menunjukkan bahwa pengungkapan informasi lingkungan berpengaruh positif dan signifikan terhadap harga saham. Maka hipotesis yang menyatakan bahwa pengungkapan informasi lingkungan berpengaruh positif pada harga saham, diterima. Hasil penelitian ini sejalan dengan Wulandari \& Hidayah (2013), Saputra (2016), Wei \& Wang (2016) serta Rahmawati \& Subardjo (2017). Berdasarkan teori stakeholder yang menyatakan bahwa semua stakeholder mempunyai hak memperoleh informasi mengenai aktivitas perusahaan yang dapat mempengaruhi pengambilan keputusan mereka. Perusahaan dengan pengungkapan informasi lingkungan yang baik akan memberikan informasi yang lebih bisa diandalkan oleh stakeholder. Makin baiknya tingkat pengungkapan oleh perusahaan akan menjadi sinyal positif yang diberikan oleh perusahaan kepada stakeholder. Nurdin \& Cahyandito (2006) menyatakan bahwa aspek kepercayaan (belief) dari investor merupakan aspek yang sangat berpengaruh dalam pasar saham. Mengungkapkan informasi lingkungan tidak hanya untuk menyediakan informasi kepada pemangku kepentingan, namun juga dapat meningkatkan reputasi dan kemampuan kompetisi perusahaan (Liu et al., 2011). Oleh sebab itu, suatu pengungkapan yang dilakukan oleh perusahaan akan membuat investor percaya kinerja perusahaan juga telah dijalankan dengan baik sehingga dapat meningkatkan citra dan nilai perusahaan serta mampu mempengaruhi para investor untuk berinvestasi. Semakin banyak permintaan akan saham dari para investor maka akan berdampak pada peningkatan harga saham.

Dari Tabel 7. diketahui bahwa nilai koefisien regresi GCG ad alah sebesar 0,317 dengan tingkat signifikansi sebesar 0,001 kurang dari tingkat signifikansi 0,050. Hal ini menunjukkan bahwa GCG berpengaruh positif dan signifikan terhadap harga saham. Maka hipotesis yang menyatakan bahwa GCG berpengaruh positif pada harga saham, diterima. Hasil penelitian ini sejalan dengan Osagie et al. (2005) Mohamed \& Elewa (2016), Ningsih \& Atmadja (2017) serta Pongkorung et al. (2018). Penerapan GCG dapat meningkatkan nilai perusahaan yang terlihat dari pergerakan harga saham. Perusahaan yang memiliki tata kelola yang baik akan berjalan lebih efisien karena aktivitasnya terkendali dengan baik. Dengan tata kelola yang baik dapat meminimalisir dampak buruk yang tidak diinginkan serta dapat meningkatkan kinerja perusahaan sehingga mampu menarik minat investor dan berdampak pada peningkatan harga saham. Berdasarkan hasil analisis faktor menunjukkan kepemilikan institusional sebagai faktor yang berpengaruh paling tinggi pada harga saham sehingga kepemilikan institusional dijadikan proksi untuk variabel GCG pada penelitian ini. Kepemilikan institusional merupakan kepemilikan saham oleh institusi yang berperan penting dalam pengawasan kinerja perusahaan. Sehingga proporsi kepemilikan institusional yang tinggi dapat membuat pengawasan kinerja perusahaan menjadi lebih terkendali dengan baik. Keefektifan kinerja perusahaan dapat meningkatkan kepercayaan stakeholder yang akan berdampak pada meningkatnya harga saham. 


\section{SIMPULAN}

Berdasarkan hasil analisis yang telah diuraikan maka dapat disimpulkan ba hwa kinerja lingkungan yang diproksikan dengan peringkat PROPER berpengaruh positif pada harga saham perusahaan. Pengungkapan informasi lingkungan yang diproksikan dengan indeks pengungkapan aspek lingkungan pada GRI G4 berpengaruh positif pada harga saham perusahaan. Good corporate governance yang diproksikan dengan kepemilikan institusional berpengaruh positif pada harga saham perusahaan pertambangan.

Berdasarkan simpulan yang telah diuraikan maka saran yang dapat diberikan yaitu untuk perusahaan pertambangan yang belum mengikuti disarankan untuk berpastisipasi menjadi peserta PROPER karena dengan mengikuti program ini akan memberikan keuntungan berupa citra baik yang akan direspon positif oleh pasar sehingga dapat meningkatkan harga saham perusahaan. Perusahaan juga disarankan untuk lebih memperhatikan dan lebih banyak memberikan informasi pengungkapan informasi lingkungan karena berdasarkan data yang dikumpulkan terdapat fluktuasi yang tinggi pada variabel pengungkapan informasi lingkungan. Bagi investor disarankan agar lebih menyadari isu-isu terkait lingkungan, menilai aktivitas perusahaan dalam menjaga lingkungan serta memperhatikan komposisi kepemilikan saham di dalam perusahaan sehingga mendapat informasi yang bisa dijadikan pertimbangan dalam keputusan investasi dengan tepat dan menguntungkan. Adapun kekurangan penelitian ini yaitu hanya meneliti pada perusahaan pertambangan sehingga sampel yang didapat sedikit. Untuk peneliti selanjutnya diharapkan memperluas sampel penelitian atau mempertimbangkan kemungkinan variabel lain yang dapat mempengaruhi harga saham sesuai dengan sektor perusahaan yang diteliti, misalnya jika pada perusahaan pertambangan disarankan untuk menggunakan variabel terkait tanggung ja wab sosial perusahaan (CSR) ataupun fundamental ekonomi makro dan jika pada perusahaan perbankan menggunakan variabel kinerja keuangan perusahaan.

\section{REFERENSI}

Ainy, R. N., \& Barokah, Z. (2016). Tata Kelola Perusahaan, Pertanggungjawaban Lingkungan, dan Kinerja Perusahaan: Bukti Empiris di Indonesia dan Malaysia. Simposiun Nasional Akuntansi XIX, (2001), 1-22.

Almilia, L. S., \& Wijayanto, D. (2007). Pengaruh Environmental Performance dan Environmental Disclosure Terhadap Economic Performance. Proceedings The 1st Accounting Conference, (7-9 November 2007).

Aryani, S., \& Cintyawati, C. (2018). Faktor-faktor yang Mempengaruhi Keputusan Investasi Mahasiswa dengan Latar Belakang Pendidikan yang Berbeda: Studi Kasus di Kota Bandung Factors Influence Investment Decision among University Student With Different Education Background: A Case Study in .05(02).

Basu, S. (1977). Investment Performance of Common Stocks in Relation to Their Price-Earning Ratios: A Test of The Efficient Marker Hypotesis. The Journal of Finance, XXXII(3), 663-682.

Brigham, E. F., \& Houston. (2006). Fundamental of Financial Management: DasarDasar Manajemen Keuangan (10th ed.). Jakarta: Salemba Empat.

Busru, S. A., \& Shanmugasundaram, G. (2017). Corporate Disclosure Scores and 
Share Price Reaction: Empirical Study of Indian Listed Firms (Post Satyam Period). SSRN Electronic Journal, 7(3), 6-8. https://doi.org/10.2139/ssrn.2926897

Cohen, L., Manion, L., \& Morrison, K. (2011). Research methods in education. New York: Routledge.

Deák, Z., \& Karali, B. (2014). Stock Market Reactions to Environmental New s in the Food Industry. Journal of Agricultural and Applied Economics, 46(2), 209225. https://doi.org/10.1017/s1074070800000742

Drobetz, W., Schillhofer, A., \& Zimmermann, H. (2004). Corporate Gover nance and Expected Stock Returns: Evidence from Germany. European Financial Management, 10(2), 267-293. https://doi.org/10.1111/j.13547798.2004.00250.x

Flammer, C. (2013). Corporate Social Responsibility and Stock Prices: The Environmental Awareness of Shareholders. Academy of Management Journal, $56(3), 1-46$.

Jensen, M. C., \& Meckling, W. H. (1976). Theory of the Firm: Managerial. Journal of Financial Economics, 3, 305-360. https://doi.org/http://dx.doi.org/10.1016/0304-405X(76)90026-X

Kusuma, I. M. E. W., \& Dewi, L. G. K. (2019). Pengaruh Kinerja Lingkungan pada Nilai Perusahaan dengan Good Corporate Governance Sebagai Variabel Pemoderasi. E-Jurnal Akuntansi Universitas Udayana, 26(3), 2183-2209.

Liu, Z. G., Liu, T. T., McConkey, B. G., \& Li, X. (2011). Empirical Analysis on Environmental Disclosure and Environmental Performance Level of Listed Steel Companies. Energy Procedia, 5, 2211-2218. https://doi.org/10.1016/j.egypro.2011.03.382

Menteri Lingkungan Hidup dan Kehutanan Republik Indonesia. Keputusan Menteri Lingkungan Hidup dan Kehutanan RI No. SK.613/Menlhk/Setjen/KUM.1/2018 Tentang Hasil Penilaian Peringkat Kinerja Perusahaan dalam Pengelolaan Lingkungan Hidup Tahun 2017-2018. , (2018).

Mohamed, W. S., \& Elewa, M. M. (2016). The Impact of Corporate Governance on Stock Price and Trade Volume. International Journal of Accounting and Financial Reporting, 6(2), 27. https://doi.org/10.5296/ijafr.v6i2.9757

Ningsih, F. S., \& Atmadja, A. S. (2017). Pengaruh Pengungkapan Good Corporate Governance terhadap Stock Return dengan Kinerja Perusahaan sebagai Variabel Mediasi pada Perusahaan LQ-45. Business Accounting Review, 5(2), 433-444.

Nurdin, E., \& Cahyandito, M. F. (2006). Pengungkapan Tema-Tema Sosial Dan Lingkungan Dalam Laporan Tahunan Perusahaan Terhadap Reaksi Investor. Jurnal Ekonomi Universitas Padjajaran, (March).

Osagie, J., Osho, G. S., \& Sutton, C. (2005). The Impacts Of Institutional Stock Ownership On Stock Returns And Performance: A Financial Market Perspective. Journal of Business \& Economics Research (JBER), 3(3), 65-70. https://doi.org/10.19030/jber.v3i3.2758

Pongkorung, A., Tommy, P., \& Tulung, J. E. (2018). Pengaruh Profitabilitas dan Struktur Kepemilikan Terhadap Harga Saham Industri Keuangan Non Bank yang Terdaftar di BEI Tahun 2012-2019. Jurnal EMBA, 6(4), 3048-3057.

Prabandari, K. R., \& Suryanawa, K. (2014). Pengaruh Environmental Performance 
Pada Reaksi Investor Di Perusahaan High Profile Bursa Efek Indonesia. EJurnal Akuntansi Universitas Udayana, 2(7), 299-312.

Pribadi, A. K. (2016). Pengaruh Harga Minyak Mentah Dunia, Dow Jones Industrial Average, dan Inflasi Terhadap Harga Saham Perusahaan Di BEI. IOSR Journal of Economics and Finance, 3(1), 1-217. https://doi.org/https://doi.org/10.3929/ethz-b-000238666

Rahmawati, M. I., \& Subardjo, A. (2017). Pengaruh Pengungkapan Lingkungan dan Kinerja Lingkungan Terhadap Kinerja Ekonomi Yang Dimoderasi Good Corporate Governance. Jurnal Buletin Studi Ekonomi, 22(2), 200-226.

Reni, F., \& Anggraini, R. (2006). Pengungkapan Informasi Sosial dan FaktorFaktor yang Mempengaruhi Pengungkapan Informasi Sosial dalam Laporan Keuangan Tahunan ( Studi Empiris pada Perusahaan-Perusahaan yang terdaftar Bursa Efek Jakarta ). Simposium Nasional Akuntansi 9 Padang, 23-26.

Samontaray, D. P. (2010). Impact of Corporate Governance on The Stock Prices of The Nifty 50 Broad Index Listed Companies. International Research Journal of Finance and Economics, 41(January 2010), 7-18.

Saputra, A. (2018). Akibat Perusahaan Buang Limbah ke Sungai Masyarakat Jadi Resah.

Saputra, F. (2016). Pengaruh Environmental Performance dan Environmental Disclosure Terhadap Economic Performance. Jurnal Universitas Lampung.

Sarumpaet, S. (2006). The Relationship Between Environmental Performance And Financial Performance of Indonesian Companies. Jurnal Akuntansi Dan Keuangan, 7(2), 89-98. https://doi.org/10.9744/JAK.7.2.PP. 89-98

Spence, M. (1973). Job Market Signaling. The Quarterly Journal of Economics, 87(3), 355-374. Retrieved from http://www.jstor.org/stable/1882010

Sulia. (2017). Analisis Faktor-Faktor Yang Mempengaruhi Harga Saham Pada Perusahaan LQ45 Yang Terdaftar Di Bursa Efek Indonesia. Jurnal Wira Ekonomi Mikroskil, 7(2), 129-140. https://doi.org/10.20961/jab.v14i1.149

Suratno, I. B., Darsono, \& Mutmainah, S. (2004). Pengaruh Environmental Performance Terhadap Environmental Disclosure dan Economic Performance (Studi Empiris pada Perusahaan Manufaktur yang Terdaftar di Bursa Efek Jakarta Periode 2001-2004). Simposium Nasional Akuntansi IX Padang, 23-26.

Tanjung, I. A. (2013). Pengaruh Good Corporate Governance Terhadap Harga Saham pada Perusahaan yang Mengikuti Pemeringkatan Corporate Governance Perception Index Indonesia.

Teja, I. G. M. A. A., Wahyuni, M. A., \& Dewi, G. A. K. R. S. (2018). Pengaruh Environmental Performance, Social Performance Dan Penerapan Carbon Management Accounting Terhadap Indeks Harga Saham (Studi Empiris Pada Perusahaan Manufaktur Dan Pertambangan Yang Terdaftar Di Bursa Efek Indonesia Periode 2015-2017). Jurnal Ilmiah Mahasiswa Akuntansi Universitas Pendidikan Ganesha, 9(3), 122-133.

Titisari, K. H., \& Alviana, K. (2012). Pengaruh Environmental Performance Terhadap Economic Performance. Jurnal Akuntansi Dan Keuangan Indonesia, 9(1), 56-67. https://doi.org/10.2139/ssrn.2820209

Utama, M. S. (2016). Aplikasi Analisis Kuantitatif. Denpasar: CV. Sastra Utama. Wahyuni, F. (2018). Nilai Perusahaan, Indeks Tata Kelola Perusahaan Dan Firm 
Value , Corporate Governance Index , and Capital Structure. Jurnal Ilmiah Akuntansi Dan Bisnis, 13(2), 151-160.

Wei, J., \& Wang, I. (2016). Environmental Disclosure, Investors' Investment Decisions and Their Perceptions of the Credibility of Management. 10(4), 17-25.

Wijaya, B. A., \& Nuryatno, M. (2019). Pengaruh Environmental Performance Dan Environmental Disclosure Terhadap Economic Performance. Jurnal Informasi, Perpajakan, Akuntansi Dan Keuangan Publik, 9(2), 141. https://doi.org/10.25105/jipak.v9i2.4530

Wulandari, R. D., \& Hidayah, E. (2013). Pengaruh Environmental Performance Dan Environmental Disclosure Terhadap Economic Performance. Jurnal Ekonomi Dan Bisnis Islam, VII(2), 233-244. https://doi.org/10.25105/jipak.v9i2.4530

Yasa, G. W., Astika, I. B. P., \& Widiariani, N. M. A. (2019). The Influence Of Accounting Conservatism, IOS, And Good Corporate Governance On The Earnings Quality. Jurnal Ilmiah Akuntansi Dan Bisnis, 14(1), 86-94. https://doi.org/10.24843/jiab.2019.v14.i01.p08

Ziegler, A., Schröder, M., \& Rennings, K. (2007). The Effect of Environmental and Social Performance on The Stock Performance of European Corporations. Environmental and Resource Economics, 37(4), 661-680. https://doi.org/10.1007/s10640-007-9082-y 